${ }^{1}$ Neuroendocrine Unit, Division of Endocrinology and Metabolism, Faculdade de Medicina da Universidade de São Paulo (FMUSP), São Paulo, SP, Brazil ${ }^{2}$ Endocrinology Service, Universidade Federal de Pernambuco (UFPE), Recife, PE, Brazil
Correspondence to: Marcio Carlos Machado Faculdade de Medicina Universidade de São Paulo, Unidade de Neuroendocrinologia, Divisão de Endocrinologia e Metabologia

Av. Dr. Enéas de Carvalho Aguiar, 155,8 o andar

05403-060 - São Paulo, SP, Brazil marciocm@usp.br

Received on Mar/29/2013 Accepted on May/23/2013

\section{Spontaneous remission of} hypercortisolism presumed due to asymptomatic tumor apoplexy in ACTHproducing pituitary macroadenoma

\author{
Remissão espontânea do hipercortisolismo devido a \\ provável apoplexia tumoral assintomática em paciente \\ com macroadenoma produtor de ACTH
}

Marcio Carlos Machado', Patricia Sampaio Gadelha², Marcello Delano Bronstein', Maria Candida Barisson Vilares Fragoso'

\section{SUMMARY}

Cushing's disease (CD) is usually caused by secretion of ACTH by a pituitary corticotroph microadenoma. Nevertheless, $7 \%-20 \%$ of patients present with $\mathrm{ACTH}$-secreting macroadenomas. Our aim is to report a 36-year-old female patient with CD due to solid-cystic ACTH-macroadenoma followed up during 34 months. The patient presented spontaneous remission due to presumed asymptomatic tumor apoplexy. She showed typical signs and symptoms of Cushing's syndrome (CS). Initial tests were consistent with ACTH-dependent CS: elevated urinary free cortisol, abnormal serum cortisol after low dose dexamethasone suppression test, and elevated midnight salivary cortisol, associated with high plasma ACTH levels. Pituitary magnetic resonance imaging (MRI) showed a sellar mass of $1.2 \times 0.8 \times 0.8 \mathrm{~cm}$ of diameter with supra-sellar extension leading to slight chiasmatic impingement, and showing hyperintensity on T2-weighted imaging, suggesting a cystic component. She had no visual impairment. After two months, while waiting for pituitary surgery, she presented spontaneous resolution of CS. Tests were consistent with remission of hypercortisolism: normal 24-h total urinary cortisol and normal midnight salivary cortisol. Pituitary MRI showed shrinkage of the tumor with disappearance of the chiasmatic compression. She has been free from the disease for 28 months (without hypercortisolism or hypopituitarism). The hormonal and imaging data suggested that silent apoplexy of pituitary tumor led to spontaneous remission of CS. However, recurrence of CS was described in cases following pituitary apoplexy. Therefore, careful long-term follow-up is required. Arq Bras Endocrinol Metab. 2013;57(6):486-9

\section{SUMÁRIO}

A doença de Cushing (DC) é usualmente causada por um microadenoma produtor de ACTH. Entretanto, 7\%-20\% dos pacientes apresentam um macroadenoma. 0 objetivo deste trabalho é reportar uma paciente de 36 anos, feminina, com diagnóstico de DC devido a macroadenoma hipofisário sólido-cístico com seguimento de 34 meses que apresentou remissão espontânea presumidamente em decorrência de uma apoplexia tumoral assintomática. Inicialmente, ela apresentava sinais e sintomas típicos da síndrome de Cushing (SC). Na admissão, os testes foram consistentes com o diagnóstico de SC ACTH-dependente: cortisol urinário livre de 24h elevado, não supressão do cortisol sérico após dose baixa de dexametasona e cortisol salivar noturno elevado, associado a concentrações elevadas do ACTH plasmático. Ressonância magnética (RM) de hipófise revelou uma massa selar de $1.2 \times 0.8 \times 0.8 \mathrm{~cm}$ com extensão suprasselar levando a uma discreta compressão do quiasma óptico e mostrando região de hipersinal na imagem ponderada em T2 sugerindo um componente cístico. A paciente não apresentava queixas visuais. Após dois meses, enquanto aguardava o tratamento cirúrgico, a paciente apresentou remissão espontânea da SC. A repetição dos exames indicou remissão do hipercortisolismo: normalização do cortisol urinário livre de $24 \mathrm{~h}$ e normalização do cortisol salivar noturno. Nova RM de hipófise revelou redução do volume tumoral com desaparecimento da compressão quiasmática. A paciente permanece livre da doença por 28 meses (sem hipercortisolismo ou hipopituitarismo). Os dados hormonais e de imagem sugerem que tenha ocorrido uma apoplexia tumoral assintomática, levando à remissão espontânea da SC. Entretanto, como há relatos de recorrência após apoplexia hipofisária, cuidadoso seguimento a longo prazo faz-se necessário. Arq Bras Endocrinol Metab. 2013;57(6):486-9 


\section{INTRODUCTION}

C ushing's disease (CD) is generally caused by excessive secretion of ACTH, usually by a pituitary corticotroph microadenoma. However, $7 \%-20 \%$ of cases are due to ACTH-producing macroadenomas (1-3).

Apoplexy is described in pituitary tumors, especially in those macroadenomas of the non-clinically functioning, prolactinomas, and GH-producing adenomas subtypes (4). In CD, these cases are infrequent and associated with macroadenomas (5-11), although there are also descriptions in patients with ACTH-producing microadenomas $(12,13)$. Nevertheless, the majority of CD patients with pituitary apoplexy described were symptomatic at the initial presentation.

The aim of the present study is to report a patient with 34 months of $\mathrm{CD}$ evolution harboring a solidcystic ACTH-macroadenoma, who presented spontaneous remission of hypercortisolism due to presumed asymptomatic tumor apoplexy.

\section{CASE REPORT}

A 36 year-old female patient was admitted to our Neuroendocrine Unit in April 2009 for evaluation of CS. She had a 7-month history of weight gain, acne, hirsutism, progressive proximal muscle weakness, arterial hypertension, and secondary amenorrhea. At admission, she showed typical clinical features of CS, BP: $160 \times 100 \mathrm{mmHg}$, $90 \mathrm{~kg}$, BMI: $35 \mathrm{~kg} / \mathrm{m}^{2}$ (with truncal obesity), and Ferriman-Gallwey score 12. Initial hormonal data were consistent with ACTH-dependent CS: elevated urinary free cortisol $(1200 / 1000 / 1180$ $\mu \mathrm{g} / 24 \mathrm{~h}$, reference $10-90 \mu \mathrm{g} / 24 \mathrm{~h}$ ), non-suppressed serum cortisol (Fs) after low-dose dexamethasone suppression test (Fs: $2.56 \mu \mathrm{g} / \mathrm{dL}$ ), and elevated plasma ACTH: $89.5 \mathrm{pg} / \mathrm{mL}$ (reference $<60 \mathrm{pg} / \mathrm{mL}$ ). Our lab assessment also confirmed CS diagnosis: 24-h urinary cortisol: $648 \mu \mathrm{g} / 24 \mathrm{~h}$ (reference $30-300 \mu \mathrm{g} / 24 \mathrm{~h}$ ), and midnight salivary cortisol: $460 \mathrm{ng} / \mathrm{dL}$ (reference $<130 \mathrm{ng} / \mathrm{dL}$ ) (Table 1). The patient showed no ACTH and cortisol responses after IV administration of desmopressin (10 $\mu \mathrm{g}$ ) (ACTH: 42.5 to $49.8 \mathrm{pg} / \mathrm{mL}$, 17.2\%; Fs: 26.7 to $27.1 \mu \mathrm{g} / \mathrm{dL}, 1.5 \%)$. Other hormonal analyses were normal (T3, FT4, TSH, IGF1, estradiol, LH, FSH, prolactin). Pituitary MRI (January 2009 ) revealed a $1.2 \times 0.8 \times 0.8 \mathrm{~cm}$ sellar mass with supra-sellar extension leading to minor optic chiasmatic compression, with hypointense signal in $\mathrm{Tl}$ and partial hyperintense in T2-weighted imaging, suggesting a solid and cystic component (Figure $\mathrm{IA}$ and $\mathrm{lB}$ ).
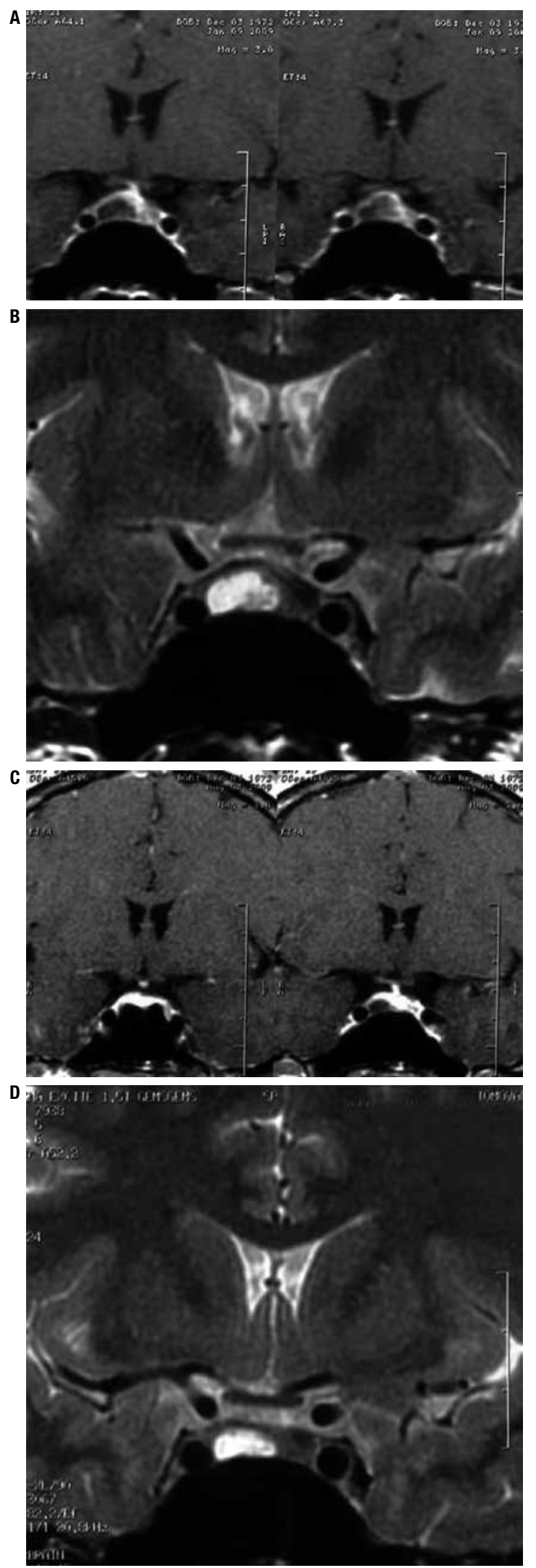

Figure 1. Pituitary magnetic resonance imaging (MRI).

(A) Initial coronal post-gadolinium T1-weighted MRI pituitary scans; (B) initial coronal T2-weighted; (C) after spontaneous remission coronal post-gadolinium T1-weighted; (D) after spontaneous remission coronal T2-weighted. 
She had no visual impairment. Thoracic and abdominal computed tomography were negative for any lesions, and serum tumor markers were in the normal range. After two months, while she was waiting for pituitary surgery without any clinical treatment, she presented spontaneous resolution of CS characterized by loss of weight $(6 \mathrm{~kg})$, return of regular periods, improvement of hypertension and hirsutism, and decreased the abdominal obesity. New tests were consistent with remission of hypercortisolism: normal 24-h urinary total cortisol and midnight salivary cortisol (Table 1, Figure 2). Subsequent pituitary MRI (August 2009) showed tumor shrinkage with disappearance of optic chiasmatic compression (Figure IC and ID). After 28 months of follow-up, she remains in clinical remission of CS and did not develop hypopituitarism. Up to today, she lost $22 \mathrm{~kg}$ (actual weight $68 \mathrm{~kg}$, BMI: $27 \mathrm{~kg} / \mathrm{m}^{2}$ ). Last imaging analysis (October 2011) was similar to the August 2009 MRI. Hormonal and imaging data suggested that silent apoplexy of pituitary tumor probably occurred, leading to spontaneous remission of CS. The patient remained in clinical remission until October 2011.

The Research Project and Graduate Studies Commission, and the Ethics Commission of our Institution approved the study, and the patient signed an informed consent form.

Table 1. Hormonal and weight evolution during patient follow-up

\begin{tabular}{|c|c|c|c|c|c|}
\hline Date & $\begin{array}{c}\text { UC } \\
\mu \mathrm{g} / 24 \mathrm{~h}\end{array}$ & $\begin{array}{c}\text { NSC } \\
\mathrm{ng} / \mathrm{dL}\end{array}$ & $\begin{array}{c}\text { LDDST } \\
\mathrm{Fs}, \mu \mathrm{g} / \mathrm{dL}\end{array}$ & $\begin{array}{c}\text { ACTH } \\
\mathrm{pg} / \mathrm{mL}\end{array}$ & $\begin{array}{c}\text { Weight } \\
\text { kg }\end{array}$ \\
\hline \multirow[t]{3}{*}{ December 2008} & $1200^{*}$ & - & 2.56 & 89.5 & 85 \\
\hline & $1000^{\star}$ & & & & \\
\hline & $1180^{\star}$ & & & & \\
\hline January 2009 & - & $2.5^{\star \star}$ & - & - & - \\
\hline April 2009 & 648 & 460 & 1.6 & - & 90 \\
\hline \multirow[t]{2}{*}{ June 2009} & 54 & $<100$ & - & - & 84 \\
\hline & 58 & & & & \\
\hline August 2009 & 47 & - & - & 24 & 78 \\
\hline November 2009 & 49 & - & - & 20 & 70 \\
\hline July 2010 & 80 & 70 & - & 25 & 68 \\
\hline November 2010 & 80 & 40 & - & - & 67 \\
\hline March 2011 & 78 & 30 & 1.1 & 34 & 67 \\
\hline October 2011 & 83 & 70 & - & 35 & 68 \\
\hline
\end{tabular}

UC: urinary cortisol, reference 30-300 $\mu \mathrm{g} / 24 \mathrm{~h}$. * Urinary free cortisol, reference 10-90 $\mu \mathrm{g} / 24 \mathrm{~h}$; NSC: nocturnal salivary cortisol, reference $<130 \mathrm{ng} / \mathrm{dL} ;{ }^{* *}$ Reference $<3.6 \mathrm{nmol} / \mathrm{L} ;$ LDDST: low-dose dexamethasone supression test; F: serum cortisol; ACTH: reference $<60 \mathrm{pg} / \mathrm{mL}$. To convert values of serum cortisol to nanomoles per liter, multiply by 27.59; urinary cortisol to nmol, multiply by 2.759 ; plasma ACTH to pmol/liter, multiply by 0.2202 .

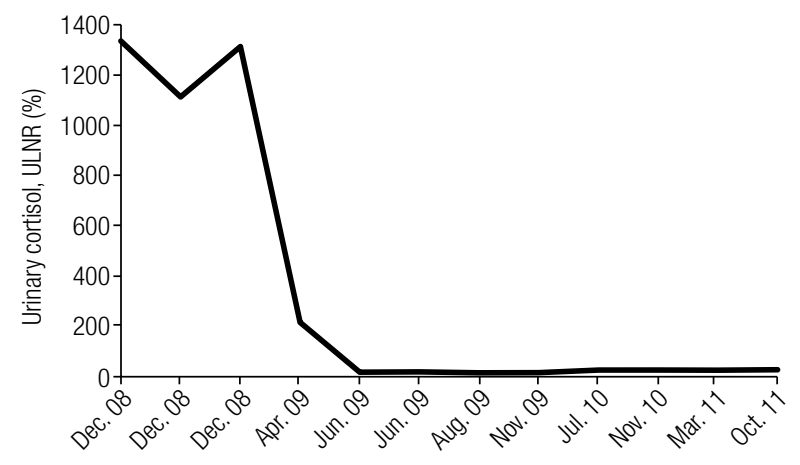

Figure 2. Urinary cortisol evolution during patient follow-up. ULNR: upper limit of normal range (\%).

\section{DISCUSSION}

Spontaneous remissions in CS and CD are infrequent events that have been already reported more than fifty years ago $(14,15)$. In the subsequent years, some other cases were published and some of them presented recurrence in the follow-up period $(7,8,16)$. However, the cyclic aspect of cortisol secretion that account for $15 \%$ of CS patients from several etiologies, mainly CD, are well-described (17). Therefore, these two clinical conditions may overlap, and some of the cases may have been mistakenly described.

Some factors are considered to explain spontaneous remission, principally pituitary apoplexy, an event that has also been enrolled as one of the mechanisms for cyclic CS.

Pituitary apoplexy is more prevalent in other pituitary adenoma subtypes. This event is infrequent in CD, occurring mainly in ACTH-secreting macroadenomas (5-11). However, it may also take place in ACTH-secreting microadenomas $(12,13)$. Pignatta and cols. reported a case of CD that showed a 3-mm microadenoma next to the pituitary stalk that, after short period of ketoconazol use, presented a sudden clinical picture of pituitary apoplexy with remission of CS and concomitant disappearance of pituitary tumor in the follow-up imaging analysis (13). Commonly, pituitary apoplexy in $\mathrm{CD}$ patients occurs spontaneously. However, others conditions, such as pituitary radiation therapy (18) or corticotrophin-releasing hormone test (19), were previous correlated with this clinical manifestation.

Pituitary apoplexy occurs as a result of infarction, hemorrhage, or a combination of hemorrhagic infarction in a pituitary tumor tissue. Apoplexy may cause a sudden enlargement of the tumor and frequently results in acute pituitary insufficiency. Patients commonly 
experience sudden onset of symptoms that may vary in severity, from headache, with or without endocrine deficiency; visual impairment; ophthalmoplegia; coma; and even death. However, many cases are subclinical or asymptomatic (20), and are suggested by pituitary imaging analysis, during pituitary surgeries or in necropsy studies. In CD patients, the majority of cases described was symptomatic and submitted to pituitary surgery.

The risk for pituitary infarction may be increased by provocative tests for pituitary reserve assessment, anticoagulation, oral contraceptive agents, and clomiphene. The susceptibility to apoplexy may also be increased by head trauma, non-pituitary surgery, pregnancy, thrombocytopenia, and increased intracranial pressure (21).

The case reported here present non-frequent aspects for $\mathrm{CD}$, such as macroadenoma secreting tumor and spontaneous remission without interventions, probably due to asymptomatic pituitary apoplexy. Other similar case was previous reported by Le Nestour and cols., but in a patient with microadenoma. In the follow-up, pituitary MRI showed spontaneous Tl-weighted hiperintensity suggestive of apoplexy, but without any clinical complaints. One year after that, new imaging analysis revealed an empty sella, and the patient achieved spontaneous CS remission (12).

Natural evolution of some pituitary adenomas is known, particularly microprolactinomas. Nevertheless, this aspect is poorly established in ACTH-secreting macroadenomas.

Finally, several cases of CD that showed initial pituitary apoplexy or spontaneous remission presented recurrence in the follow-up up to seven years after remission $(7,8,16,22)$. Alarifi and cols. reported a case of macroadenoma with some two-year periods of spontaneous remission after clinical pituitary apoplexy events (8).

Therefore, careful long-term follow-up is required for patients with CD following remission after pituitary apoplexy, in order to detect hypercortisolism recurrence or the development of hypopituitarism.

Disclosure: no potential conflict of interest relevant to this article was reported.

\section{REFERENCES}

1. Blevins LS Jr, Christy JH, Khajavi M, Tindall GT. Outcomes of therapy for Cushing's disease due to adrenocorticotropin-secreting pituitary macroadenomas. J Clin Endocrinol Metab. 1998;83:63-7.

2. Katznelson L, Bogan JS, Trob JR, Schoenfeld DA, Hedley-Whyte $\mathrm{ET}$, Hsu DW, et al. Biochemical assessment of Cushing's disease in patients with corticotroph macroadenomas. J Clin Endocrinol Metab. 1998;83:1619-23.

3. Woo YS, Isidori AM, Wat WZ, Kaltsas GA, Afshar F, Sabin I, et al. Clinical and biochemical characteristics of adrenocorticotropin-secreting macroadenomas. J Clin Endocrinol Metab. 2005;90:4963-9.

4. Randeva HS, Schoebel J, Byrne J, Esiri M, Adams CB, Wass JA. Classical pituitary apoplexy: clinical features, management and outcome. Clin Endocrinol (Oxf). 1999;51:181-8.

5. Araya V, Solís I, Lemp M, Oviedo S. Partial remission of hypercortisolism in Cushing disease after pituitary apoplexy. A case report. Rev Med Chil. 1998;126:1497-501.

6. Miranda M, Barros L, Knopfelmacher M, Augusto EC, Jacomossi A, Cukiert $A$, et al. Pituitary apoplexy followed by endocrine remission. Report of two cases. Arq Neuropsiquiatr. 1998;56:449-52.

7. Kamiya Y, Jin-No Y, Tomita K, Suzuki T, Ban K, Sugiyama N, et al. Recurrence of Cushing's disease after long-term remission due to pituitary apoplexy. Endocr J. 2000;47:793-7.

8. Alarifi A, Alzahrani AS, Salam SA, Ahmed M, Kanaan I. Repeated remissions of Cushing's disease due to recurrent infarctions of an ACTH-producing pituitary macroadenoma. Pituitary. 2005;8:81-7.

9. Haboubi H, Azam I, Edavalath M, Redfern RM, Price DE, Stephens JW. Apoplexy in a corticotrophin-secreting pituitary macroadenoma: a case report and review of the literature. QJM. 2010;103:607-9.

10. Sahin SB, Cetinkalp S, Erdogan M, Cavdar U, Duygulu G, Saygili $\mathrm{F}$, et al. Pituitary apoplexy in an adrenocorticotropin-producing pituitary macroadenoma. Endocrine. 2010;38:143-6.

11. Messer CK, Fowkes ME, Gabrilove JL, Post KD, Son H, Levine AC. ACTH-producing remnants following apoplexy of an ACTH-secreting pituitary macroadenoma. Pituitary. 2012;15 Suppl 1:S6-9.

12. Le Nestour E, Abécassis JP, Bertagna X, Bonnin A, Luton JP. Silent necrosis of a pituitary corticotroph adenoma revealed by timely magnetic resonance imaging: a cause of spontaneous remission of Cushing's disease. Eur J Endocrinol. 1994;130:469-71.

13. Pignatta AB, Díaz AG, Gómez RM, Bruno OD. Spontaneous remission of Cushing's disease after disappearance of a microadenoma attached to the pituitary stalk. Pituitary. 2004;7:45-9.

14. Pasqualini RQ, Gurevich N. Spontaneous remission in a case of Cushing's syndrome. J Clin Endocrinol Metab. 1956;16:406-11.

15. Hayslett JP, Cohn GL. Spontaneous remission of Cushing's disease. Report of a case. N Engl J Med. 1967;276:968-70.

16. Ishibashi M, Shimada K, Abe K, Furue H, Yamaji T. Spontaneous remission in Cushing's disease. Arch Intern Med. 1993;153:251-5.

17. Alexandraki KI, Kaltsas GA, Isidori AM, Akker SA, Drake WM, Chew SL, et al. The prevalence and characteristic features of cyclicity and variability in Cushing's disease. Eur $\mathrm{J}$ Endocrinol. 2009;160:1011-8.

18. OhtsukaT, Hanew K, Sugawara A, Goh M, Sato S, ShimizuY, et al. A case of Cushing's disease resulting in remission due to pituitary apoplexy during radiation therapy. Nippon Naika Gakkai Zasshi. 1988;77:1095-6.

19. Rotman-Pikielny P, Patronas N, Papanicolaou DA. Pituitary apoplexy induced by corticotrophin-releasing hormone in a patient with Cushing's disease. Clin Endocrinol (Oxf). 2003;58:545-9.

20. Onesti ST, Wisniewski T, Post KD. Clinical versus subclinical pituitary apoplexy: presentation, surgical management, and outcome in 21 patients. Neurosurgery. 1990;26:980-6.

21. Vella A, Young W. Pituitary apoplexy. Endocrinologist. 2001;11:282-8.

22. Mercado-Asis LB, Oldfield EH, Cutler GB Jr. Pituitary tumor hemorrhage in Cushing disease. Ann Intern Med. 1995;122:189-90. 